\title{
PERGESERAN PERAN DAN FUNGSI RADIO SUARA SURABAYA DARI RADIO INFORMASI MENJADI RADIO PENGADUAN
}

\author{
Sampoerno $^{1}$, Seto Herwandito ${ }^{2}$, Dewi Kartika Sari ${ }^{3}$ \\ ${ }^{1,2,3}$ Dosen Program Studi Ilmu Komunikasi - Universitas Kristen Satya Wacana Salatiga \\ Email: dewi.kartika@staff.uksw.edu
}

\begin{abstract}
Abstrak
Penelitian ini bertujuan untuk mengidentifikasi faktor-faktor penyebab pergeseran fungsi Radio Suara Surabaya. Penelitian ini juga memaparkan alasan pergerseran tersebut bisa terjadi. Dalam meneliti pergeseran fungsi radio Surabaya dari fungsinya yang semula dan mengapa pergeseran tersebut terjadi, peneliti menggunakan pendekatan penelitian kualitatif dengan jenis penelitian deskriptif. Pada tahap awal penelitian ini, peneliti mengidentifikasi fungsi awal pendirian radio Suara Surabaya yakni sebagai radio informasi. Selanjutnya peneliti memaparkan pergeseran fungsi radio Suara Surabaya menjadi fungsi pengaduan. Terakhir peneliti mengidentifikasi alasan pergeseran fungsi radio tersebut. Pada tahapan untuk menjaga kredibilitas data penelitian, peneliti melakukan triangulasi data dengan melakukan studi literatur tentang radio dan manajemen radio.
\end{abstract}

Kata Kunci: Pergeseran Fungsi, Radio, Suara Surabaya, Informasi, Pengaduan

\begin{abstract}
This study aims to identify factors causing the shift function of Radio Suara Surabaya. This research also explains the reason for the shift to occur. In examining the shift of Radio Suara Surabaya function from its original function and why the shift occurred, the researcher uses a qualitative research approach with descriptive research type. In the early stages of this study, the researchers identified the initial function of the establishment of Radio Suara Surabaya as an information radio. Furthermore, it describes the shift of voice function of Radio Suara Surabaya into a grievance function. Finally the researchers identified the reason for the radio function shift. At the stage to maintain the credibility of research data, researchers conducted data triangulation by conducting literature studies on radio and radio management.
\end{abstract}

Key Words: Function Shift, Radio, Suara Surabaya, Information, Grievance.

\section{PENDAHULUAN \\ Latar Belakang}

Nama Suara Surabaya sejatinya ditujukan untuk menyuarakan suara masyarakat Surabaya (anonim, 2008). Pada laman suarasurabaya.net tersebut disampaikan bahwa nama Suara Surabaya dirumuskan bersama oleh Soetojo Soekomihardjo, Direktur Utama Suara Surabaya, dan Errol Jonathans, Direktur Operasional Suara Surabaya Media. Soetojo dan Errol merupakan pendiri dan perintis radio yang bermarkas di Puncak Wonokriti Besar 40C. Rumusan nama Suara Surabaya tersebut selanjutnya disebut sebagai visi Suara Surabaya. Nama tersebut mencerminkan apa yang akan diperbuat oleh Suara Surabaya dan nama 
tersebut juga menunjukkan arah tujuan radio Suara Surabaya akan beroperasi.

Tulisan mengenai 'Suara Surabaya' Bukan Mentereng Gengsi pada laman website resmi Suara Surabaya, selanjutnya menyatakan bahwa pada saat pendirian radio Suara Surabaya, yang dipikirkan pada waktu itu adalah bagaimana radio ini dapat berguna untuk kota Surabaya. Radio Suara Surabaya disebutkan dibuat khusus untuk kota Surabaya. Kemunculan radio Suara Surabaya yang memilih lokasi pendirian di Surabaya tersebut, karena menurut Soetojo, peraturanlah yang mengharuskan seperti itu. Soetojo menyebut peraturan tersebut harus kerdil, yakni cuma di kota Surabaya.

Pemilihan nama "Suara Surabaya" dijelaskan Soetojo memang memiliki tujuan khusus. Tujuan pemilihan nama tersebut adalah untuk memberikan beban kepada radio Suara Surabaya, agar yang disiarkannya tidak macam-macam dan tidak berbobot. Ditambahkan oleh Soetojo, Suara Surabaya nantinya akan ditagih masyarakat Surabaya, karena nama radio ini sudah menyandang nama kota Surabaya. Pencapaian pengakuan sebagai radio masyarakat Surabaya inilah yang ingin diperjuangkan oleh radio Suara Surabaya.

Pencapaian pengakuan sebagai radionya masyarakat Surabaya ini, dalam perjalanannya menemukan hasil yang unik. Hasil unik tersebut adalah dilaporkannya kejadian pencurian dan kehilangan di Surabaya oleh masyarakat Surabaya. Kejadiankejadian tersebut diantaranya adalah tertangkapnya pencuri mobil jenis pick up (2013, p. 15), tertangkapnya pencuri mobil jenis Pajero Sport (2012a), ditemukannya mobil rental yang hilang (2012b), dan ditemukannya anak autis yang hilang (2010). Semua kejadian tersebut berasal dari laporan warga Surabaya ke radio Suara Surabaya.

Beberapa kejadian pencurian dan kehilangan yang dilaporakan warga Surabaya ke radio Suara Surabaya tersebut, diakomodir oleh Suara Surabaya melalui laman website-nya. Kejadian-kejadian tersebut dapat dilihat di website Suara Surabaya bagian "Untung ada SS". Hal inilah yang kemudian menjadi alasan peneliti untuk melakukan penelitian mengenai pergeseran fungsi radio Suara Surabaya.

Dengan demikian, rumusan masalah yang diajukan adalah: (1) Bagaimana pergeseran fungsi radio informasi Suara Surabaya menjadi radio pengaduan yang terjadi di radio Suara Surabaya?; (2) Mengapa pergeseran fungsi tersebut bisa terjadi?

\section{Konteks Penelitian}

Konteks Penelitian ini yakni berfokus pada media massa khususnya Radio Suara Surabaya. Dalam kajian Ilmu Komunikasi, penekanan penelitian ini pada pergeseran fungsi Radio Suara Surabaya dari radio informasi menjadi radio pengaduan.

\section{HASIL KAJIAN PUSTAKA}

\section{Komunikasi Massa}

Komunikasi massa (mass communication) awalnya merupakan studi yang berkaitan dengan bagaimana hubungan antara media massa dan masyarakat. McQuail dalam bukunya yang berjudul MacQuail's Mass Communication Theory menyebutkan abad pertama media massa yakni pada abad ke-20 (McQuail, 2010). Pada abad ini ditandai dengan berubahnya keheranan maupun ketakutan atas pengaruh media massa. Meski terjadi perubahan besar dalam lembaga dan teknologi media serta perubahan besar yang terjadi dalam masyarakat, serta muculnya "ilmu komunikasi", namun perdebatan publik mengenai signifikansi sosial yang potensial dari "media" sepertinya tidak terlalu berubah.

Perdebatan publik yang tidak terlalu berpengaruh tersebut adalah terdapat tiga set ide yang merupakan kepentingan khusus sejak awal. Ide pertama berkenaan dengan kekuasaan (power) dari alat baru komunikasi; ide yang kedua berkaitan dengan pertanyaan 
mengenai integrasi (integration) sosial atau disintegrasi yang mungkin disebabkan oleh media; dan ide yang ketiga merupakan pertanyaan mengenai pencerahan (enlightment) publik yang mereka dorong atau mereka hilangkan.

\section{Fungsi Komunikasi Massa}

Komunikasi massa kemudian dijelaskan oleh Effendy memiliki fungsi diantaranya: (a) Informasi; (b) Sosialisasi; (c) Motivasi; (d) Perdebatan dan diskusi; (e) Pendidikan; (f) Memajukan kebudayaan; dan (g) Hiburan (Effendy, 2002:122).

\section{Jenis-jenis Komunikasi Massa}

McQuail ( 2010:24) menyebutkan tentang jenis-jenis media massa, yakni :

a. Media Cetak. Yang termasuk dalam kategori media cetak menurut McQuail di sini adalah buku dam surat kabar. Pers cetak selanjutnya memunculkan berbagai bentuk publikasi diantaranya drama (plays), lagu, artikel, cerita berseri, puisi, pamflet, komik, laporan, prospektus, peta, poster, musik, brosur, surat kabar dinding, dan masih banyak lagi. Hal yang lebih penting lainnya adalah majalah berkala (mingguan atau bulanan).

b. Film sebagai media massa. Film di awal abad ke-19 merupakan bentuk teknologi baru, tetapi konten dan fungsi yang ditawarkan masih sangat jarang. Film selanjutnya berubah menjadi alat presentasi dan distribusi dari tradisi hiburan yang lebih tua, menawarkan cerita, panggung, musik, humor, drama, dan trik teknis bagi konsumsi populer. Film juga hampir menjadi media massa yang sesungguhnya dalam artian bahwa film mampu menjangkau populasi dalam jumlah besar dengan cepat, bahkan di wilayah pedesaan. Sebagai media massa, film merupakan bagian dari respons terhadap penemuan waktu luang, waktu libur dari kerja, dan sebuah jawaban atas tuntutan untuk cara menghabiskan waktu luang keluarga yang sifatnya terjangkau dan (biasanya) terhormat.

c. Penyiaran. Televisi dan radio telah menempuh waktu yang cukup panjang yakni sembilan puluh dan enam puluh tahun lebih sejarah sebagai media massa. Keduanya tumbuh dari teknologi yang telah ada sebelumnya, yaitu telepon, telegraf, fotografi bergerak atau diam, dan rekaman suara. Ciri utama dari radio dan televisi adalah besarnya peraturan, kontrol, atau lisensi oleh penguasa yang awalnya datang dari kebutuhan teknis, kemudian dari campuran antara pilihan demokratis, kepentingan negara, kenyamanan ekonomi, dan budaya lembaga yang bebas. Ciri kedua dari radio dan televisi adalah pola distribus yang terpusat dengan pasokan datang dari pusat kota tanpa adanya arus timbal balik. Disebutkan oleh McQuail bahwa barangkali karena kedekatan mereka dengan kekuasaan, radio dan televisi sulit mendapatkan kebebasan yang sama, seperti yang dimiliki pers, untuk mengekspresikan pandangan dan tindakan dengan kebebasan berpolitik. Penyiaran selanjutnya dianggap terlalu memiliki pengaruh yang kuat untuk jatuh ke tangan kepentingan tertentu tanpa batasan jelas dalam melindungi publik dari bahaya atau manipulasi yang potensial.

d. Musik Rekaman. McQuail menyebutkan, relatif sangat sedikit perhatian yang diberikan kepada musik sebagai media massa dalam teori dan penelitian. Mungkin karena dampaknya tidak terlalu jelas, tetapi juga tidak ada berhentinya kemungkinan yang ditawarkan penerus teknologi rekaman dan reproduksi/penyebaran. Rekaman musik bahkan tidak memiliki label yang nyaman untuk menggambarkan perwujudan media yang banyak, walaupun istilah fonogram sudah disarankan untuk media yang meliputi musik yang diakses melalui pemutar kaset, pemutar CD, VCR, siaran, kabel, dan seterusnya. 
Penelitian ini secara khusus akan membahas mengenai penyiaran, yakni radio. Terkhusus akan meneliti radio Suara Surabaya.

\section{Konsep Dasar Manajemen}

Konsep manajemen telah dikemukakan oleh beberapa ahli. Dalam buku Pengantar Teori dan Manajemen Komunikasi disebutkan beberapa konsep dasar mengenai Manajemen. Koonts dan O'Dannell (1980) misalnya menyatakan manajemen dimaknai sebagai pelaksanaan sesuatu dengan menggunakan orang lain (getting things done throughout people); Goerge R. Terry memaknai manajemen sebagai sebuah proses yang khas, yang terdiri dari tindakan-tindakan: perencanaan, pengorganisasian, penggiatan, dan pengawasan yang dilakukan untuk menentukan serta mencapai sasaran- sasaran yang sudah ditetapkan melalui pemnafaatan sumber daya manusia dan sumber-sumber lainnya; Oey Liang Lee mengatakan bahwa manajemen adalah sebuah seni perencanaan, pengorganisasian, pengarahan, pengkoordinasian, dan pengontrolan atas human and national resources guna mencapai tujuan yang telah ditetapkan terlebih dahulu; Frans Sadikin mengatakan manajemen adalah proses untuk menciptakan, memelihara, dan mengoperasikan organisasi perusahaan dengan tujuan tertentu melalui upaya manusia yang sistematis, terkoordinasi dan kooperatif, maka proses penentuan asas-asas pokok perusahaan yang menjadi batasan, pedoman, dan penggerak bagi setiap manusia dalam perusahaan, sudah termasuk dalam pengertian manajemen. Dengan demikian, kesimpulan yang bisa diperoleh dari berbagai macam pendapat ahli tersebut bahwa manajemen merupakan sebuah proses untuk melakukan perencanaan (planning), pengorganisasian (organizing), penyusunan staff (staffing), pengarahan (leading), dan pengawasan (controlling) (Suprapto, 2009:121) .

\section{Manajemen Media Massa}

Manajemen dalam sebuah organisasi menjadi penting dilakukan, tak terkecuali diterapkan dalam lingkungan organisasi media massa. Pendekatan manajemen di perusahaan media massa dibutuhkan karena tanpa manajemen, tujuan organisasi media massa tersebut tidak akan tercapai. Telah kita pahami bersama bahwa alasan utama dibutuhkannya manajemen adalah untuk mencapai tujuan organisasi, dalam hal ini adalah organisasi media massa. Oleh karena itu, penerapan fungsi-fungsi manajemen, yakni planning, organizing, staffing, leading, dan controlling harus dijalankan. Dalam konteks penelitian ini, peneliti akan melihat penerapan dari fungsi manajemen dalam organisasi media massa, khususnya radio Suara Surabaya.

\section{Jenis-Jenis Lembaga Penyiaran}

Sebagaimana dijelaskan didalam Undang-Undang Nomor 32 Tahun 2009 Pasal 13 ayat (2) bahwa lembaga penyiaran diselenggarakan oleh :

a) Lembaga Penyiaran Publik, yakni lembaga penyiaran yang berbentuk badan hukum yang didirikan oleh negara, bersifat independen, netral, tidak komersial, dan berfungsi memberikan layanan untuk kepentingan masyarakat;

b) Lembaga Penyiaran Swasta, adalah lembaga penyiaran yang bersifat komersial berbentuk badan hukum Indonesia, yang bidang usahanya hanya menyelenggarakan jasa penyiaran radio atau televisi;

c) Lembaga Penyiaran Komunitas, merupakan merupakan lembaga penyiaran yang berbentuk badan hukum Indonesia, didirikan oleh komunitas tertentu, bersifat independen, dan tidak komersial, dengan daya pancar rendah, luas jangkauan wilayah terbatas, serta untuk melayani kepentingan komunitasnya; dan 
d) Lembaga Penyiaran Berlangganan, merupakan merupakan lembaga penyiaran berbentuk badan hukum Indonesia, yang bidang usahanya hanya menyelenggarakan jasa penyiaran berlangganan dan wajib terlebih dahulu memperoleh izin penyelenggaraan penyiaran berlangganan.

\section{Tujuan Penelitian}

Tujuan khusus dari penelitian ini antara lain:

1. Untuk mengetahui proses terjadinya pergeseran fungsi radio informasi Suara Surabaya menjadi radio pengaduan yang terjadi di radio Suara Surabaya.

2. Untuk mengetahui alasan terjadinya pergeseran fungsi radio Suara Surabaya.

\section{RANCANGAN PENELITIAN}

\section{Lokasi Penelitian}

Penelitian ini dilakukan di Radio Suara Surabaya yang berlokasi di Surabaya selama 6 (enam) bulan.

\section{Sumber Data}

Sumber data penelitian ini ada dua, sumber data primer dan sumber data sekunder. Sumber data primer adalah sumber data dengan melakukan wawancara secara mendalam dengan CEO Radio Suara Surabaya, Errol Jonathans dan Manager Radio Suara Surabaya, Edi. Sumber data sekunder diperoleh dengan cara mengambil data-data seperti jurnal, buku, atau dokumen dari pemberitaaan surat kabar.

\section{Teknik Pengumpulan Data}

Dalam pengumpulan data prinsipnya dapat dilakukan melalui tiga cara utama:

1. Melakukan wawancara mendalam dengan informan yang merupakan pelopor petisi, untuk memahami aspek, peristiwa, kegiatan yang berkaitan dengan permohonan. Wawancara mendalam dapat dilakukan juga dengan informan kunci / orang / kelompok yang memahami / mengikuti tentang petisi dan aksi dari petisi.

2. Melakukan dengan hati-hati pengamatan dari semua kegiatan / acara yang berhubungan dengan petisi Pengamatan dapat dilakukan dengan menggunakan kamera, handycam, atau dengan mengambil catatan langsung ke acara yang ada, seperti mengambil foto dari media, kegiatan, publikasi, dan lain-lain.

3. Data sekunder yang berkaitan dengan statistik, website, facebook, twitter, dan lain-lain.. Data yang dicatat meliputi penduduk, wilayah, negara geografi, topografi, dan lain-lain.

\section{Analisis Data}

Analisis data kualitatif menurut Yusuf (2017:401), dapat dilakukan dengan dua cara, yakni analisis data sebelum ke lapangan dan analisis data selama di lapangan. Analisis data sebelum ke lapangan diperoleh dari buku, jurnal, atau sumber data lain yang terkait dengan penelitian yang dilakukan. Analisis ini juga berguna dalam penentuan fokus penelitian yang akan digunakan. Meskipun demikian, data dan fakta yang nantinya diperoleh saat pengambilan data di lapangan dapat disesuaikan dengan penelitian, tapi peneliti tidak boleh tergiring ke analisis yang ditentukan sebelum ke lapangan.

Analisis data setelah ke lapangan, di sisi lain, dapat dilakukan dengan mengadopsi teknik analisis data yang dikemukakan oleh Miles dan Huberman (dalam Yusuf, 2017:407). Analisis data yang dikenal dengan analisis data model alir, dilakukan dengan cara : (1) reduksi data (data reduction); (2) data display (display data); (3) penarikan kesimpulan/verifikasi. 


\section{HASIL DAN PEMBAHASAN}

\section{Radio Suara Surabaya: Bergeserkah Perannya dari Radio Swasta menjadi "Radio} Publik"?

\section{Sejarah Perkembangan Radio di Indonesia4 ${ }^{1}$}

Perkembangan radio di Indonesia dimulai pada zaman penjajahan Belanda, tepatnya di tahun 1911, dimana Angkatan Laut Kerajaan Belanda pertama kali mengoperasikan fasilitas radio komunikasi di Sabang. Radio pada awalnya dahulu pada masa penjajahan Belanda digunakan sebagai alat komunikasi mengatur jalur kapal laut di Selat Malaka. Setelah itu di Jakarta tahun 1925 didirikan BRV, Batavia Radio Society atau Radio Batavia Vereniging $(B R V)$ yang terdiri dari beberapa broadcaster yang mulai mengudarakan siaran tetap berupa pemutaran musik dari luar negeri.

Lahirnya BRV inilah yang menjadi pionir sebagai radio siaran di Hindia Belanda (Indonesia). Pada 8 Maret 1942, saat Belanda menyerahkan diri kepada Jepang, radio siaran juga ikut diberhentikan. Radio tidak hanya mati sampai disitu, akan tetapi Jepang mendirikan lembaga penyiaran baru yang dinamakan Hoso Kanri Kyoko dengan cabang-cabangnya di Jakarta, Bandung, Purwokerto, Semarang, Yogyakarta, Surakarta, Surabaya, dan Malang. Lembaga penyiaran di delapan daerah inilah yang kemudian menjadi cikal bakal Radio Republik Indonesia (RRI). Masa radio kemudian terbagi menjadi beberapa era, yaitu Era Kemerdekaan Indonesia (Orde Lama, 1945-1965); Orde Baru (1966-1998); Era Reformasi.

Di era Kemerdekaan Indonesia, Radio menjadi poros untuk mengampanyekan proklamasi kemerdekaan bangsa Indonesia pada 17 Agustus 1945 kepada dunia. RRI mulai didirikan oleh pemerintah Indonesia sebagai stasiun radio resmi pertama milik pemerintah pada 11 September 1945. Usaha mengkampanyekan ini berbuah hasil karena mendapat simpati dari Negara-negara tetangga mengenai kemerdekaan Republik Indonesia.

Di masa Orde Baru, adanya kekuasaan politik ikut berperan terhadap perkembangan Radio Republik Indonesia, saat itu RRI sebagai satu-satunya alat siar milik pemerintah. Adanya Partai Komunis Indonesia (PKI) dan militer juag berpengaruh untuk menyiarkan propagandanya. Sehingga RRI menjadi media yang lebih condong untuk menyiarkan atau memberikan informasi terkait dengan kepentingan pemerintah.

Radio Siaran Non Pemerintah diatur dalam Peraturan Pemerintah Nomor 55 Tahun 1970. Dalam peraturan tersebut, konten siaran radio non pemerintah diwajibkan memiliki fungsi sosial, yaitu sebagai alat pendidik, penerangan, hiburan, bukan alat untuk kegiatan politik. Selain itu, sistem kepemilikan media hanya terkonsentrasi pada sejumlah golongan yang berpengaruh di masa pemerintahan Orde Baru. Hal ini ditunjukkan ketika anak pertama Presiden Soeharto, Siti Hardianti Rukmana yang ditunjuk sebagai ketua umum Persatuan Radio Siaran Swasta Nasional Indonesia (PRSSNI) yang bertugas mengelola penyiaran radio swasta di Indonesia.

Di Era Reformasi ditandai dengan adanya demo dan kerusuhan menjadi titik awal media juga ikut berubah terutama dalam kebebasan untuk berkreasi dan berkarya. Para pengusaha banyak yang terjun ke dalam media penyiaran menjadi pemilik media radio. Adanya revisi UU Penyiaran No. 32 Tahun 2002 memberikan suatu nuansa yang baru, namun, hal tersebut tidak memiliki dampak yang signifikan terhadap industri radio di Indonesia. Dominasi pemilik media masih didominasi oleh segelintir elit yang memiliki pengaruh cukup tinggi di pemerintahan. Akan tetapi, apabila dibandingkan dengan UU Penyiaran sebelumnya, revisi UU Penyiaran yang dilakukan dirasa jauh lebih demokratis.

\footnotetext{
${ }^{1}$ Ekonomi Kreatif: Rencana Pengembangan Televisi dan Radio 2015-2019 (http://indonesiakreatif.bekraf.go.id/ ikpro/wp-content/uploads/2015/07/Rencana-Pengembangan-Televisi-dan-Radio-Nasional.pdf).
} 
Hal ini terlihat dari diakuinya empat macam lembaga penyiaran, yaitu lembaga penyiaran publik, komunitas, swasta, dan berlangganan, serta didirikannya juga lembaga independen perwakilan publik yang bertindak sebagai regulator sistem penyiaran yang berlaku.

Perkembangan teknologi internet yang cepat menjadi peluang dan ancaman bagi industri radio. Sekarang ini banyak dari stasiun radio yang tidak perlu menggunakan antenna yang tinggi untuk menjangkau masyarakatnya, banyak dari stasiun radio ini memanfaatkan platform streaming seperti Youtube, Vimeo, Netflix, serta webstreaming lainnya yang menyiarkan konten-konten acara televisi dan radio di Indonesia.

Era media digital ditandai dengan perubahan yang jauh lebih terbuka, keragaman pasar semakin tinggi dalam waktu yang sangat singkat. Tren konten acara yang diminati oleh masyarakat menjadi sangat cepat berubah. Semua orang kini bisa memproduksi acara (contoh Citizen Journalism) amatir oleh masyarakat dan dapat langsung disiarkan secara luas kepada publik melalui internet tanpa adanya proses pendistribusian atau pengemasan konten acara yang sistematis seperti pada stasiun televisi dan radio, ataupun rumah produksi profesional. Konten berita-berita aktual yang menampilkan peristiwa kejahatan, kerusuhan, serta maraknya kasus korupsi, apabila tidak dikelola dengan baik, maka akan dapat memprovokasi ataupun menimbulkan keresahan masyarakat. Konten berita yang disiarkan kini memiliki unsur independensi yang sangat rendah, terkadang kepentingan politis ikut campur dalam suatu produksi berita sehingga berita tidak lagi menjadi objektif dan independen, dan terjadi kesimpangsiuran fakta yang terjadi sesungguhnya.

\section{Awal Mula Frekuensi Langsung Frekuensi FM}

Untuk menjawab pergeseran fungsi radio Suara Surabaya, penelitian ini mencerita terlebih dahulu mengenai awal pendirian Radio Suara Surabaya. Menurut keterangan hasil wawancara dengan CEO Radio Suara Surabaya, Errol Jonathans, Suara Surabaya merupakan radio ketiga di Surabaya yang memiliki frekuensi FM. Radio Suara Surabaya (SS) merupakan radio pertama yang langsung memiliki frekuensi FM. SS langsung memiliki frekuensi FM karena pada saat itu tidak mendapat lisensi AM. Dengan demikian, menurut persepsi masyarakat Surabaya, SS merupakan radio dengan frekuensi FM pertama.

\section{Visi dan Misi Radio Suara Surabaya}

Selanjutnya mengenai visi dan misi Radio Suara Surabaya sejak awal berdirinya, disampaikan oleh Errol bahwa pada tahun 2000, SS memiliki satu visi dan empat misi yang penting, yakni :

1. Visi SS sebagai sumber pemberdaya dan kegiatan demokratisasi masyarakat. Fungsi SS disini adalah mengikuti perkembangan teknologi komunikasi dan telekomunikasi. Dengan demikian, SS melihat kedekatan teknologi terhadap produk-produk atau bisnis yang dimiliki Suara Surabaya.

2. Misi: (1) SS sebagai perusahaan media massa yang dituntut berkembang dengan mengandalkan kemajuan teknologi komunikasi dan telekomunikasi. (2) SS sebagai sentra informasi tentang Surabaya dan Jawa Timur. (3) SS menyelenggarakan berbagai kegiatan pemberdayaan proses demokratisasi masyarakat dan (4) SS sebagai sumber kehidupan dan kesejahteraan seluruh unsur karyawan yang bekerja untuk kemajuan bersama.

Dalam perkembangannya, Radio SS mengembangkan tujuh roh koorporasi. Tujuh roh korporasi ini mengacu pada versi business innovation direction awards yang diterima Radio SS tahun 2005. Ketujuh roh tersebut diantaranya: (1) Suara Surabaya organisasinya berbasis pada kualitas; (2) peranan teknologi informasi dalam pengembangan bisnis; dan (3) kepemimpinan di ranah masyarakat. Yang dimaksud dengan kepemimpinan di 
masyarakat ini adalah pengaruh Radio SS di publik. Bagaimana SS menjadi tempat masyarakat untuk melakukan sesuatu kemudian mengandalkan Suara Surabaya untuk membantu menyelesaikan problem-problem masyarakat.

\section{Fungsi Radio Suara Surabaya Saat Awal Mula Berdiri}

Errol Jonathans menyampaikan bahwa awalnya Radio Suara Surabaya diharapkan mirip dengan koran. Pendiri Suara Surabaya-lah yang menyampaikan konsep ini kepada Errol. Radio SS pada saat itu diharapkan menjadi media massa. Hal ini dilatarbelakangi fakta bahwa radio pada masa tersebut diisi dengan sandiwara, request, dan lain-lain yang intinya adalah hiburan. Acara-acara tersebutlah yang pada jaman itu menjadi kekuatan radio. Pendiri SS saat itu menghendaki agar Radio SS memiliki fungsi yang berbeda.

Selain fakta mengenai kekuatan radio, menurut Errol, jurnalistik pada masa tersebut merupakan sesuatu yang sangat eksklusif dan ditakuti. Hal ini disebabkan adanya larangan dari Pemerintah pada masa tersebut. Errol menambahkan, bahwa pada tahun 1984, Pemerintah mengeluarkan SK Menpen No. 226 yang isinya melarang radio swasta yang memiliki konsep berita. Kemudian di SK tersebut eksplisit disebutkan bahwa hak untuk menyiarkan berita hanya boleh dilakukan oleh Radio Republik Indonesia (RRI) yang merupakan radio milik pemerintah. Hak siar untuk berita oleh RRI ini, disebutkan oleh McQuail bahwa barangkali karena kedekatan mereka (radio dan televisi) dengan kekuasaan, radio dan televisi sulit mendapatkan kebebasan yang sama, seperti yang dimiliki pers, untuk mengekspresikan pandangan dan tindakan dengan kebebasan berpolitik. Penyiaran selanjutnya dianggap terlalu memiliki pengaruh yang kuat untuk jatuh ke tangan kepentingan tertentu tanpa batasan jelas dalam melindungi publik dari bahaya atau manipulasi yang potensial.

Pembahasan mengenai radio, sejatinya juga membahas mengenai jenis-jenis komunikasi massa. McQuail (2010:24) menyebutkan tentang jenis-jenis media massa, yakni:

a. Media Cetak. Yang termasuk dalam kategori media cetak menurut McQuail disini adalah buku dam surat kabar. Pers cetak selanjutnya memunculkan berbagai bentuk publikasi diantaranya drama (plays), lagu, artikel, cerita berseri, puisi, pamflet, komik, laporan, prospektus, peta, poster, musik, brosur, surat kabar dinding, dan masih banyak lagi. Hal yang lebih penting lainnya adalah majalah berkala (mingguan atau bulanan).

b. Film sebagai media massa. Film di awal abad ke-19 merupakan bentuk teknologi baru, tetapi konten dan fungsi yang ditawarkan masih sangat jarang. Film selanjutnya berubah menjadi alat presentasi dan distribusi dari tradisi hiburan yang lebih tua, menawarkan cerita, panggung, musik, humor, drama, dan trik teknis bagi konsumsi populer. Film juga hampir menjadi media massa yang sesungguhnya dalam artian bahwa film mampu menjangkau populasi dalam jumlah besar dengan cepat, bahkan di wilayah pedesaan. Sebagai media massa, film merupakan bagian dari respons terhadap penemuan waktu luang, waktu libur dari kerja, dan sebuah jawaban atas tuntutan untuk cara menghabiskan waktu luang keluarga yang sifatnya terjangkau dan (bisaanya) terhormat.

c. Penyiaran. Televisi dan radio telah menempuh waktu yang cukup panjang yakni sembilan puluh dan enam puluh tahun lebih sejarah sebagai media massa. Keduanya tumbuh dari teknologi yang telah ada sebelumnya, yaitu telepon, telegraf, fotografi bergerak atau diam, dan rekaman suara. Ciri utama dari radio dan televisi adalah besarnya peraturan, kontrol, atau lisensi oleh penguasa yang awalnya datang dari kebutuhan teknis, kemudian dari campuran antara pilihan demokratis, kepentingan negara, kenyamanan ekonomi, dan budaya lembaga yang bebas. Ciri kedua dari radio 
dan televisi adalah pola distribusi yang terpusat dengan pasokan datang dari pusat kota tanpa adanya arus timbal balik.

d. Musik Rekaman. McQuail menyebutkan, relatif sangat sedikit perhatian yang diberikan kepada musik sebagai media massa dalam teori dan penelitian. Mungkin karena dampaknya tidak terlalu jelas, tetapi juga tidak ada berhentinya kemungkinan yang ditawarkan penerus teknologi rekaman dan reproduksi/penyebaran. Rekaman musik bahkan tidak memiliki label yang nyaman untuk menggambarkan perwujudan media yang banyak, walaupun istilah fonogram sudah disarankan untuk media yang meliputi musik yang diakses melalui pemutar kaset, pemutar CD, VCR, siaran, kabel, dan seterusnya.

Membicarakan mengenai fungsi radio, tentu tidak terlepas pula dengan fungsi komunikasi massa. Komunikasi massa kemudian dijelaskan memiliki fungsi diantaranya: (a) Informasi; (b) Sosialisasi; (c) Motivasi; (d) Perdebatan dan diskusi; (e) Pendidikan; (f) Memajukan kebudayaan; dan (g) Hiburan (Effendy, 2002:122).

Dengan melihat pada fungsi media massa, khususnya radio, nampak bahwa pada masa awal berdirinya radio di Indonesia, difungsikan untuk tujuan hiburan berupa sandiwara radio dan request. Fungsi informasi, dalam hal ini konten berita, hanya dimiliki oleh radio pemerintah, yakni RRI.

\section{Pergeseran Fungsi: Mengapa?}

Jika dikaitkan dengan fungsi komunikasi massa, Joseph R. Dominick (Effendy, 2005: 29-31), menambahkan bahwa komunikasi massa memiliki fungsi fungsi antara lain pengawasan, yang terbagi menjadi 2 yaitu pengawasan peringatan (warning or beware surveillance) dan pengawasan instrumental (instrumental surveillance). Pengawasan peringatan lebih menitikberatkan pada penyampaian informasi mengenai ancaman bencana, kondisi ekonomi yang mengalami penurunan, meningkatnya inflasi, atau serangan militer secara serentak dan dalam waktu yang lama. Sedangkan pengawasan instrumental menitikberatkan pada penyebaran informasi dalam kehidupan sehari hari yang berguna bagi masyarakat.

Fungsi lain dari radio adalah interpretasi, dimana fungsi ini berkaitan dengan menyajikan fakta, data, dan informasi beserta interpretasi mengenai suatu peristiwa khususnya dalam hal politik berupa kritikan, fungsi ini sering disebut sebagai fungsi watchdog atau anjing penjaga. Komunikasi massa juga berfungsi untuk menghubungkan unsur-unsur yang terdapat dalam masyarakat yang tidak bisa dilakukan secara langsung oleh saluran perseorangan. Fungsi lainnya dari radio adalah fungsi hiburan dimana radio memberikan hiburan kepada masyarakat sebagai suatu kebutuhan

Sebagaimana sudah dibahas di bagian sebelumnya bahwa Radio SS memiliki pengalaman unik dengan warga Surabaya. Pengalaman unik tersebut adalah dilaporkannya kejadian pencurian dan kehilangan di Surabaya oleh masyarakat Surabaya. Kejadiankejadian tersebut diantaranya adalah tertangkapnya pencuri mobil jenis pick up (2013, p. 15), tertangkapnya pencuri mobil jenis Pajero Sport (2012a), ditemukannya mobil rental yang hilang (2012b), dan ditemukannya anak autis yang hilang (2010). Semua kejadian tersebut berasal dari laporan warga Surabaya ke radio Suara Surabaya.

Beberapa kejadian pencurian dan kehilangan yang dilaporkan warga Surabaya ke radio Suara Surabaya tersebut, dituliskan oleh Suara Surabaya di laman website-nya. Kejadian-kejadian tersebut dapat dilihat di website Suara Surabaya bagian "Untung ada SS". Ada pula pengalaman mengenai adanya kebakaran yang melanda suatu daerah di Surabaya, warga yang melihat melaporkan kejadian tersebut kepada Radio Suara Surabaya. Disusul informasi yang berkaitan dengan kebakaran tersebut, secara kronologi 
warga mulai bersahut sahutan dalam mengawal kejadian tersebut. Anehnya adalah warga melaporkan kejadian ini kepada pihak radio bukan kepada petugas pemadam kebakaran atau polisi. Bahkan dalam suatu penggalan wawancara on-air di saat warga melaporkan kejadian tersebut, penyiar Radio Suara Surabaya menanyakan apakah warga (atau orang yang memberikan informasi) sudha memberitahukan informasi ini kepada pihak yang berwajib, jawabnya "belum". Berikut penggalan wawancara tersebut:

\section{Penyiar: Selamat siang Radio Suara Suarabaya100FM \\ Warga: Selamat Siang Radio SS, ingin menginformasikan bahwa di daerah Gubeng terjadi Kebakaran, tepatnya di RT 4, RW, Pak \\ Penyiar: Apakah bapak sudah menginformasikan kepada pihak yang berwajib? \\ Warga: Belum pak..cepat pak ini apinya sudah menjalar sangat cepat...mohon cepat ditangani pak...}

Pengalaman unik ini menarik ketika kita sandingkan dengan fungsi Radio SS pada awalnya sebagai radio berita. Radio berita utamanya ditujukan untuk memberitakan situasi di sekitar, bertambah fungsinya menjadi warga yang melaporkan situasi sekitar mereka kepada radio. Konsep ini menjadi dekat dengan konsep "citizen journalism" dimana warga yang menjadi "jurnalis" atau reporter untuk masyarakat itu sendiri. Dengan demikian, radio memiliki fungsi sebagai media dalam penyampaian informasi dari masyarakat kepada masyarakat. Radio bukan lagi institusi yang "one to many" tetapi menjadi media "many to many". Partisipasi warga menjadi jantung dari Radio SS ini, alih-alih Radio SS sebagai sumber utama informasi.

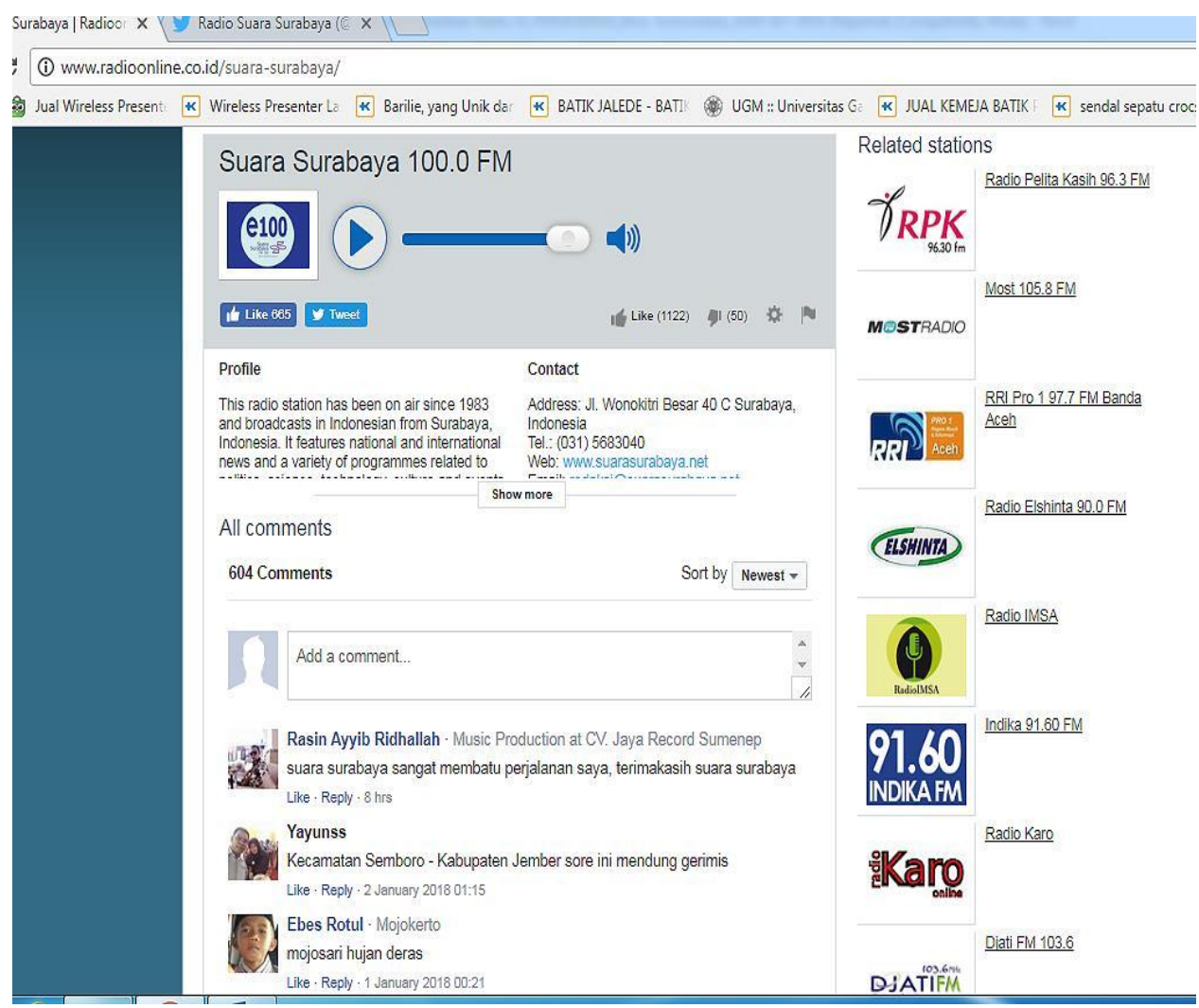




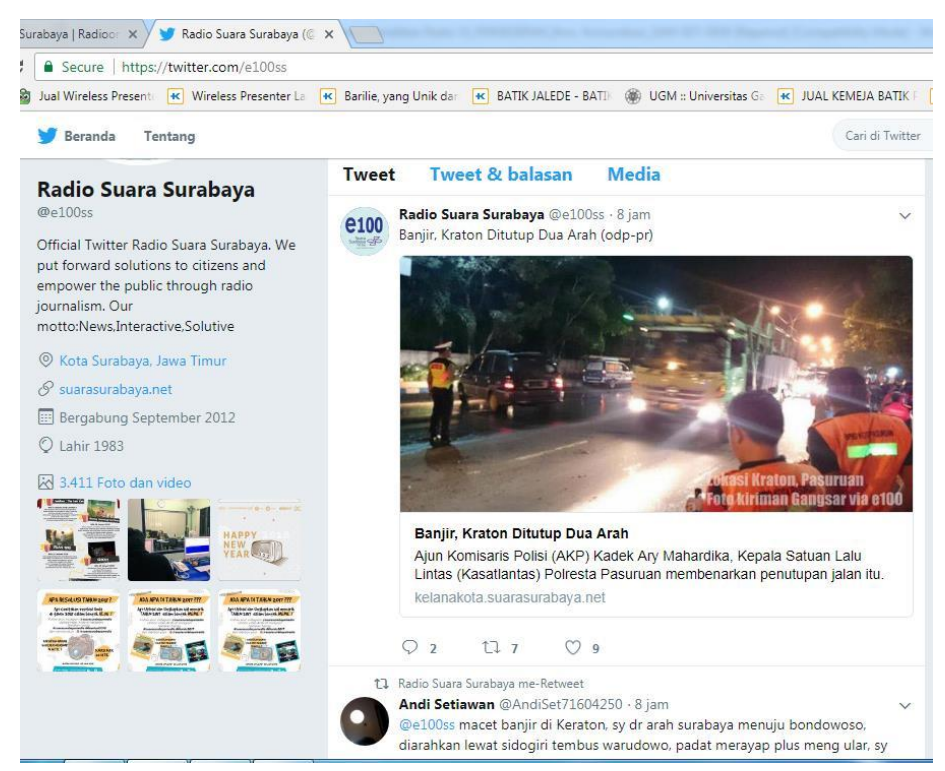

Twitter di radio SS (@e100ss), Sumber http://twitter.com/e100ss)

Dari penggalan wawancara dan gambar tersebut sebenarnya fungsi dari Radio Suara Surabaya bukan hanya sebagai media penyiaran, pengawasan, hiburan ataupun sosialisasi, akan tetapi fungsi radio ini sudah berubah menjadi fungsi pengaduan, dimana masyarakat mengadu suatu hal kepada radio, bukan kepada pihak yang berwajib. Menurut KKBI daring (https://kbbi.kemdikbud.go.id) pengaduan berasal dari kata "adu" dimana artinya adalah (kata benda) penyabungan, proses, cara, perbuatan mengadu, atau ungkapan rasa tidak senang atau tidak puas akan hal-hal yang tidak begitu penting, tetapi perlu diperhatikan.

Pengaduan dalam hal ini bisa berarti masyarakat mengungkapkan rasa tidak senang atau tidak puas terhadap sesuatu tetapi perlu diperhatikan. Ketidakpuasan masyarakat bisa terjadi karena masyarakat merasa kinerja dari instansi yang berwajib kurang memuaskan, alih-alih mengadu kepada instansi tersebut, masyarakat lebih nyaman mengadu kepada radio.

Mengapa fungsi radio berubah? Paling tidak ada 2 alasan yang dapat diutarakan mengapa pergeseran fungsi ini terjadi, yaitu: (1) kontrol dan (2) perkembangan masyarakat. Radio yang merupakan media massa memiliki fungsi media massa yang serempak, luas dan cepat. Sebagai contoh adalah terdapat kasus warga mengadu mengenai masalah lalu lintas, tentu saja hubungan lalu lintas instansi yang terkait adalah kepolisian. Apabila warga mengadu kepada kepolisian, maka komunikasi yang terjadi adalah antara kepolisian dan warga dan sebaliknya. Sehingga kontrol kepada kepolisian hanya terbatas kepada warga yang melapor. Lain ceritanya apabila kasus ini dilempar ke radio, maka yang mengkontrol bukan saja warga yang melapor, melainkan semua warga baik dari Surabaya dan wilayah lain yang termasuk dari jangkauan radio SS. Hal inilah yang dirasa penting, karena control terhadap suatu instansi bukan hanya milik satu warga yang melapor, akan tetapi milik semua warga yang peduli akan kinerja suatu instansi tersebut, sehingga akan semakin terkontrol apabila semua warga turut berperan serta aktif dalam mengkontrol instansi tersebut.

Alasan yang kedua adalah perkembangan masyarakat. Karakteristik masyarakat sekarang ini sangat berbeda dengan sebelumnya, terlebih dengan adanya media baru yang semakin membuat masyarakat menjadi semakin berkembang. Reaktif merupakan kata yang cocok digunakan untuk masyarakat sekarang ini, seperti yang ditulis oleh James Ball dalam 
bukunya "Post Truth: How Bullshit Conquer the World (2017)”. Masyarakat sekarang ini sudah tidak lagi mempedulikan mengenai suatu informasi itu benar atau tidak, fakta atau hoax, melainkan lebih cenderung kepada informasi tersebut sedang "naik daun"/ nge-tren atau tidak. Berbagai informasi muncul baik dalam media massa atau new media, sehingga mana informasi yang paling banyak menyita perhatian masyarakatnya, maka informasi itulah yang sedang diperbincangkan, dibicarakan atau dipedulikan masyarakatnya.

Tak lepas juga dengan SS, dimana SS sendiri melakukan yang namanya konvergensi media, dimana gabungan dari berbagai media seperti media massa, new media (facebook, twitter, website, Instagram, radio streaming), dan lain-lain dilebur menjadi satu dengan "bendera" Radio Suara Surabaya.

Menurut Errol, terjadinya pergeseran fungsi Radio SS yang awalnya merupakan radio informasi menjadi "radio pengaduan" salah satunya diakibatkan oleh perkembangan teknologi. Errol menyebutkan:

"Saya sekarang mencoba untuk membaginya lebih pendek, kita nggak bisa lagi bikin satu dekade. Kita mulai berpikir pendek. Kenapa? Karena perubahan itu terlampau cepat. Teknologi-teknologi itu yang mengubah semuanya sebenernya. Sehingga kemudian yang kita pikirkan hari ini dalam 5 tahun ke depan ini adalah konvergensi sinergi on air dan off air."

Perkembangan teknologi yang mempengaruhi keberadaan Radio SS ini rupanya telah disadari oleh Radio SS. Radio SS kemudian telah mengambil langkah-langkah untuk mensinergikan "on air" dan "off air". Artinya bahwa SS menggunakan berbagai media untuk menyampaikan informasinya kepada masyarakat, baik dengan menggunakan radio yang berantena hingga ke twitter. Sehingga apabila ada aduan dari warga mengenai suatu kasus, dan aduan ini dilempar ke berbagai media jaringan Radio Suara Surabaya maka aduan tersebut akan menjadi perhatian masyarakat luas. Hal ini tentu berbeda apabila SS masih tetap menggunakan radio yang ber-antena, dan informasi aduan hanya disampaikan melalui radio yang ber-antena tersebut. Efek dari masyarakat yang mengetahui informasi aduan tersebut tentu tidak se-reaktif pada informasi yang di-share melalui berbagai media. Hal inilah yang membuat fungsi radio berubah dari pusat informasi menjadi tempat pengaduan.

Tentu saja pergeseran ini tidak berbuah begitu saja, akan tetapi membutuhkan waktu yang lumayan cukup lama. Hal ini terjadi dikarenakan rasa kepercayaan masyarakat kepada SS yang sudah terbina selama puluhan tahun. Menjadikan masyarakat tidak memiliki sekat-sekat dalam suatu hal terhadap radio dan bahkan merasa "nyaman dan aman" untuk berkomunikasi dengan radio SS. Sebagai contoh di saat peristiwa tahun 1998, Indonesia mengalami kerusuhan yang terjadi di berbagai wilayah, tak luput adalah Kota Surabaya, dalam peristiwa ini banyak bangunan yang dirusak, dibakar, dirobohkan, termasuk juga bank. Saat itu ATM atau Anjungan Tunai Mandiri menjadi tempat yang vital dan penting. Masyarakat kota Surabaya mencari tahu mengenai informasi keberadaan ATM yang aman melalui radio SS, bukan melalui bank terkait. Hal ini berarti masyarakat sudah memiliki kepercayaan yang tinggi sejak tahun 1998 kepada radio SS.

Selain itu Radio SS yang senantiasa memperhatikan masyarakat menjadikan hubungan mutualisme yang berlandaskan kepercayaan ini berlangsung terus menerus hingga sekarang. Keterbukaan, transparansi, news, interaktif dan solutif menjadi salah satu kunci untuk membangun kepercayaan masyarakat ini. 


\section{REFERENSI}

anonim. (2008, June 16). suarasurabaya.net - Suara Surabaya” Bukan Mentereng Gengsi. Retrieved February 15, 2017, from http://www.suarasurabaya.net/sshut/ss_sejarah.php?id=ndnkck681sp5gtti5

anonim. (2010, Agustus). suarasurabaya.net - Hilang di Ketintang, Ditemukan di Jembatan Merah. Retrieved February 15, 2017, from http://www.suarasurabaya.net/sshut/ss_untung.php?id=ndnkck681sp5gtti50rnqohr432 010197

anonim. (2012a, Oktober). suarasurabaya.net - Kerjasama SS, Pendengar, dan Polisi Tangkap Pencuri Pajero Sport. Retrieved February 15, 2017, fromhttp://www.suarasurabaya.net/sshut/ss_untung.php?id=ndnkck681sp5gtti50rnqoh r432012216

Ball, James (2017, Mei). Post Truth: How Bullshit Conquer the World, Biteblack Publishing. Edy. (2012b, June 9). suarasurabaya.net - Kerjasama SS-Pendengar-Polisi, Hentikan Mobil Rental Yang Dilaporkan Hilang. Retrieved February 15, 2017, from http://www.suarasurabaya.net/sshut/ss_untung.php?id=ndnkck681sp5gtti5 Ornqohr432012208

Edy. (2013, January 3). suarasurabaya.net - Kurang Dari 15 Menit, Kerjasama SSPendengar-Polisi Tangkap Pencuri Mobil. Retrieved February 15, 2017, from http://www.suarasurabaya.net/sshut/ss_untung.php?id=ndnkck681sp5gtti5 Ornqohr432013217

Effendy, O. U. (2002). Ilmu Komunikasi Teori dan Praktek. Bandung: PT Remaja Rosdakarya.

2005. Ilmu, Teori dan Filsafat Komunikasi. Bandung PT.

Remaja Rosdakarya.

2006. Ilmu Komunikasi: Teori dan Praktek. Bandung: PT. Remaja Rosdakarya.

Kamus Besar Bahasa Indonesia, (https://kbbi.kemdikbud.go.id)

McQuail, D. (2010). McQuail's Mass Communication Theory (6th ed.). London: Sage Publications Ltd.

Norman, K Denzin and Yvona S Lincoln. (1994). Handbook of Qualitative Research: Constructivist, Interpretivist approaches to Human Inquiry Spradley

James P. (1979) The Ethnographic Interview. New York: Holt, Rinehart and Winston.

Schulte Nordholt, Nico. (1973). Metodologi dan Metodik Sosiologi. Lembaga Penelitian Ilmu- Ilmu Sosial, Universitas Kristen Satya Wacana, Salatiga.

Suprapto, M.A., Drs. Tommy. (2009). Pengantar Teori dan Manajemen Komunikasi. Yogyakarta: Media Pressindo.

Undang-Undang Republik Indonesia Nomor 32 Tahun 2002 Tentang Penyiaran.

Twitter di radio SS (@e100ss), Sumber http://twitter.com/e100ss).

Yusuf, Prof. Dr. A. Muri. 2017. Metode Penelitian: Kuantitatif, Kualitatif, dan Gabungan. Jakarta : Prenada Media. 